\title{
Variation in Saltgrass Growth and Time of Fall Dormancy Related to Geographical and Climatic Factors
}

\author{
Hrvoje Rukavina and Harrison Hughes ${ }^{1}$ \\ Colorado State University, Department of Horticulture and Landscape Architecture, \\ Fort Collins, CO 80523
}

\author{
Randy Johnson \\ USDA Forest Service, 1601 North Kent Street, RPC-4, Arlington, VA 22209
}

\begin{abstract}
AdDitional INDEX wORDs. turfgrass breeding, phenotypic variability, cold hardiness, warm-season turfgrass
ABstract. Development of a new turfgrass cultivar requires an evaluation of numerous traits as well as an understanding of environmental factors influencing those traits. Growth or ability to fill in gaps and time of fall dormancy (fall color retention) that indicates cold hardiness are important traits for turfgrasses. This study was initiated to characterize variation in saltgrass [Distichlis spicata L. (Greene)] growth and time of fall dormancy related to climatic and geographical factors at the source location (geographical location of clone origin). Growth traits and time of fall dormancy were measured on 52 saltgrass clones collected from 41 locations and established at one location (common garden) in Fort Collins, CO. Principal component analysis on the morphological traits extracted the first principal component that explained $78 \%$ of the variability. The first principal component and time of fall dormancy were related to climatic and geographical factors at the source locations. Variation in growth traits was related to seasonal climatic variables of summer drying and fall cooling that explained $\approx \mathbf{5 0} \%$ of variability in morphological traits. Variation in time of fall dormancy was related to longitude of clone origin and minimum winter temperature. These two variables explained $\approx \mathbf{6 0} \%$ of the total variability in time of fall dormancy. Information obtained in this study may help breeders identify the best environments for specific traits and suggests that cold tolerance could be a problem for some clones from western sources if established too far east.
\end{abstract}

Increased population growth and periods of drought in the semiarid western United States have increased demands for potable water. Consequently, many golf courses in dry western regions rely heavily on irrigation with nonpotable water (Hughes et al., 2002; Kopec and Marcum, 2001). As demands for potable water increase in the West, there is interest in developing alternative turfgrass species that offer potential for reduced irrigation requirements as well as irrigation with nonpotable (often high-saline) water. Colorado State University is currently evaluating saltgrass and other native U.S. grasses for their potential use as turf. Saltgrass tolerates extended drought and irrigation with high-saline water (Rukavina, 2006).

Like many other native grass species, saltgrass has an adaptation to particular niche environments. It is well adapted to grow in very harsh soil conditions, and tolerates highly alkaline soils and certain metals like selenium (Eppley et al., 1998; Hauser, 2006), which enables saltgrass to become dominant in environments with adverse conditions.

Correlations between variation in traits and environmental factors of plant origin suggest that natural selection has led to adaptive variation to particular environments. Environmental factors are commonly measured directly as climatic or indirectly as geographical variables (St Clair et al., 2005). It is generally thought that adaptation to local environments has generated variability within grass species (Casler and Duncan, 2003). Humphreys and Eagles (1988) found a strong positive

Received for publication 3 July 2007. Accepted for publication 5 Oct. 2007. We thank Yaling Qian and Leigh Towill for suggestions for the improvement of this manuscript. We also thank Dana Christensen for use of plant material. ${ }^{1}$ Corresponding author. E-mail: harrison.hughes@colostate.edu. correlation between perennial ryegrass (Lolium perenne L.) freezing tolerance and mean temperature of the coldest month at the ecotype origin. The amount of heterochromatin and frequency of repeated DNA sequences of tall fescue (Festuca arundinacea $\mathrm{L}$.) was strongly related to the latitude of clone origin (Ceccarelli et al., 1992). This suggests that structural changes in DNA have enabled tall fescue adaptation to different geographical locations. The decline in the presence of orchardgrass (Dactylis glomerata L.) in Japan has been related to the increase in the mean summer temperature in southern parts of Japan as well as the decrease in the lowest temperature before snowfall in northeast parts of the country (Sugiyama, 2003). Erickson et al. (2004) reported that longitude of ecotype origin was the most important variable that explained morphological and physiological differences among three geographically distinct groups of the native self-pollinated grass blue wildrye (Elymus glaucus Buckley). Ram et al. (2004) determined that large phenotypic variation occurred among 37 saltgrass ecotypes, but were not able to relate morphological traits to locations of clone origin. In that study, the relationship between geographical and genetic distance of saltgrass ecotypes was very weak, indicating that genetic interaction existed between geographically distant saltgrass ecotypes.

Efficient selection in a saltgrass breeding program necessitates characterization of germplasm in relation to environmental (climatic and geographical) factors. Determination of environmental factors that are most strongly related to variation in a specific trait can be useful to identify environments that may be best suited for particular clones. This study considers phenotypic variation of saltgrass growth and time of fall dormancy (fall color retention) as a function of geographical 
and climatic factors at the location of a saltgrass clone's origin as a first step in identifying potential new saltgrass turf cultivars.

\section{Materials and Methods}

A total of 52 clones from 41 different locations were chosen from a larger collection of saltgrass breeding material at Colorado State University. Clones were selected with the intention of covering a broad range of environmental conditions over which saltgrass is distributed in the central and western United States (Table 1). Clones were established by transplanting in Summer 2003 at the Horticultural Research Center at Colorado State University in Fort Collins, CO. Each clone was established in two $5 \times 5$-m plots in a randomized complete block design. The soil was a Nunn clay loam (mesic Aridic Argiustoll). No fertilizers were applied and the field was left unmowed. Irrigation was applied weekly during the summer by using a linear move irrigation sprinkler system.

Latitude, longitude, and elevation were obtained for each location of clone origin (Maps a la carte, 1999). The climatic conditions for each location were obtained from geographical information system (GIS) layers generated by the PRISM (parameter elevation regressions on independent slopes model) statistical geographical model, which estimates mean monthly and annual temperature and precipitation, mean minimum and maximum monthly temperature, and the average dates of the last and the first frost for $4 \times 4-\mathrm{km}$ grid cells (Daly et al., 1994).

Clone traits measured were time of fall dormancy (fall color retention) and growth traits (canopy height, internode length, leaf length, and leaf width). All measurements were performed by averaging two plants per clone. Time of fall dormancy or fall color retention is an indicator of saltgrass freezing tolerance. In freezing tolerance experiments performed in Colorado, saltgrass clones with better freezing tolerance turned brown (dormant) earlier in fall, whereas those less tolerant remained green longer (Rukavina et al., 2007). Leaf color of clones was visually evaluated in the fall using a 9-point color scale. On the color scale, grade 9 represented completely green grass and grade 1 represented completely brown, dormant grass. Grade 5 represented the stage when $\approx 50 \%$ of the leaf area turned brown (Rukavina et al., 2007). Color evaluation was periodically performed in October and Nov. 2004. Growth traits were measured in late August/early Sept. 2004. Canopy height was measured from the soil level to the tip of the tallest leaf of plant in centimeters. Internode length (in millimeters) was measured on the three lowest internodes of three stems. Leaf length was measured in centimeters on the three lowest leaves on three stems from the stem to the tip of the leaf. Leaf width was measured in millimeters at the base of the three lowest leaves on three stems.

All statistical analyses were performed with SAS software (version 8; SAS Institute, Cary, NC). The experiment was analyzed as a randomized complete block design with two blocks or replicates. Analysis of variance (PROC MIXED) was performed to determine the effect of location of clone origin on measured traits. Analysis of variance included several models in which each trait of interest presented a function of three random factors: source locations, clones nested within locations, and blocks or replicates.

Principal component analysis (PROC PRINCOMP) was performed on the data set for leaf length, canopy height, and internode length. The first principal component (PC-1) explained most of the variation in traits of growth and was used as the estimate of "growth" in further analysis. Relationships between measured traits and geographical and climatic factors at locations of clone origin were determined using correlation and regression. Simple and multiple regression models were constructed by regressing growth (PC-1) and average rating of time of fall dormancy (dependent variables) on geographical and climatic factors (independent variables). Geographical factors included latitude, longitude, and elevation as well as the interaction term between latitude and longitude. Estimated climatic variables included monthly and annual precipitation and temperature (mean, minimum, and maximum) as well as several seasonal rate variables identified in the regression analyses; fall cooling (September maximum temperature - October maximum) and summer drying (June mean precipitation - August mean precipitation). Model building was performed by using the $R^{2}$ selection method of the PROC REG procedure. The best model was assumed to be the one that explained the greatest amount of variability with fewest terms. Maps of the predicted values for time of fall dormancy and growth were constructed for the selected regression models. Map construction was performed by retrieving the relevant independent variables from the regression equations in GIS data layers on a $4 \times 4-\mathrm{km}$ grid. Retrieved data were then used in the prediction equations to generate estimates for time of fall dormancy and growth. Different colors were used to represent ranges of predicted values in each grid.

\section{Results and Discussion}

Results from analysis of variance indicated that canopy height, internode length, and leaf length differed among locations of clone origin. Time of fall dormancy and leaf width did not differ significantly among locations of origin (Table 2). Because time of fall dormancy had a probability very close to 0.05 , it was retained for further analysis. Leaf width was removed from the data set. An analysis of variance considered a simple location effect that may or may not be associated with environmental (geographical and climatic) conditions present at the location of clone's origin.

The PC-1 from the principal component analysis explained $78 \%$ of the variability in the three morphological characteristics and had an eigenvalue of 2.35 . The remaining two principal components had eigenvalues less than one and explained only a small percent of the total variability. Based on these results, only PC-1 was retained for further analyses and was used to represent a value for growth in these clones.

Growth was negatively correlated with summer drying $(r=$ $-0.38, P=0.014)$ and positively correlated with fall cooling $(r=0.37, P=0.015)$. The initial correlation analysis between growth (PC-1) and the climatic and geographical factors only found significant negative correlations of growth with spring $(r=-0.39, P=0.009)$ and early summer $(r=-0.41, P=0.006)$ precipitation. This type of association may be explained by clone water use efficiency. The clones originally from arid areas may generally use water more efficiently than the plants from humid climates. In a common garden, water is equally available to all plants, so the plants from drier locations may grow more with the water applied than those from more humid locations. A water use efficiency study with the arid land habitat shrub Chrysothamnus nauseosus (Pallas) Britt. (Donovan and 
Table 1. Latitudes, longitudes, and climatic factors (mean precipitation, maximum and minimum temperature) of sampling locations of saltgrass clones used in the study that considered phenotypic variation in saltgrass growth and time of fall dormancy as a function of geographical and climatic factors at the location of the clone's origin.

\begin{tabular}{|c|c|c|c|c|c|c|}
\hline Clone & Location & $\begin{array}{l}\text { Latitude } \\
\left({ }^{\circ} \mathrm{N}\right)\end{array}$ & $\begin{array}{l}\text { Longitude } \\
\left({ }^{\circ} \mathrm{W}\right)\end{array}$ & $\begin{array}{l}\text { Precipitation } \\
(\mathrm{mm})\end{array}$ & $\begin{array}{l}\text { Maximum } \\
\text { temperature } \\
\left({ }^{\circ} \mathrm{C}\right)\end{array}$ & $\begin{array}{c}\text { Minimum } \\
\text { temperature } \\
\left({ }^{\circ} \mathrm{C}\right)\end{array}$ \\
\hline 1220 & Ruby Valley, NV & 40.360 & 115.447 & 482 & 13.34 & -0.61 \\
\hline 1250 & Carlin, NV & 40.714 & 116.103 & 238 & 16.57 & -0.53 \\
\hline 1260 & Ruby Lake, NV & 40.183 & 115.471 & 326 & 15.99 & -1.15 \\
\hline 1280 & Deeth, NV & 41.066 & 115.274 & 313 & 15.97 & -2.92 \\
\hline 1330 & Wendover, UT & 40.737 & 114.037 & 162 & 16.82 & 3.51 \\
\hline 1420 & Evanston, WY & 41.268 & 110.963 & 316 & 12.17 & -2.47 \\
\hline 1440 & Green River, WY & 41.529 & 109.466 & 203 & 14.88 & -3.01 \\
\hline 1460 & Sturgis, SD & 44.410 & 103.509 & 550 & 15.12 & 1.00 \\
\hline 1490 & Chamberlain, SD & 43.811 & 99.330 & 538 & 15.99 & 2.54 \\
\hline 1720 & Ansley, NE & 41.288 & 99.381 & 626 & 16.20 & 1.60 \\
\hline 1840 & Lusk, WY & 42.763 & 104.452 & 418 & 14.33 & -1.06 \\
\hline C1660 & Humboldt Sink, NV & 39.973 & 118.606 & 136 & 19.61 & 1.36 \\
\hline $\mathrm{C} 1100$ & Pueblo, CO & 38.254 & 104.609 & 322 & 19.65 & 2.10 \\
\hline A1210 & Denver, CO & 39.739 & 104.984 & 413 & 17.59 & 2.75 \\
\hline A1350 & Denver, CO & 39.739 & 104.984 & 413 & 17.59 & 2.75 \\
\hline A1370 & Denver, CO & 39.739 & 104.984 & 413 & 17.59 & 2.75 \\
\hline A1390 & Denver, CO & 39.739 & 104.984 & 413 & 17.59 & 2.75 \\
\hline A1410 & Denver, CO & 39.739 & 104.984 & 413 & 17.59 & 2.75 \\
\hline A1500 & Aurora, CO & 39.729 & 104.831 & 444 & 17.59 & 1.43 \\
\hline A1530 & Aurora, CO & 39.729 & 104.831 & 444 & 18.14 & 1.43 \\
\hline A1650 & Aurora, CO & 39.729 & 104.831 & 444 & 18.14 & 1.43 \\
\hline A1970 & Longmont, $\mathrm{CO}$ & 40.167 & 105.101 & 356 & 18.16 & 0.79 \\
\hline A11070 & Longmont, $\mathrm{CO}$ & 40.167 & 105.101 & 356 & 18.16 & 0.79 \\
\hline A11230 & Wellington, CO & 40.704 & 105.008 & 374 & 16.76 & 1.36 \\
\hline A11260 & Timnath, CO & 40.529 & 104.985 & 356 & 17.47 & 1.71 \\
\hline A11370 & Timnath, CO & 40.529 & 104.985 & 356 & 17.47 & 1.71 \\
\hline 130610 & Cheyenne, WY & 41.140 & 104.820 & 420 & 16.65 & 0.21 \\
\hline 130630 & Guernsey, WY & 42.270 & 104.741 & 348 & 17.50 & 0.30 \\
\hline 130760 & Scotts Bluff, NE & 41.838 & 103.697 & 383 & 16.97 & 0.71 \\
\hline 130880 & Chadron, NE & 42.829 & 102.999 & 423 & 16.32 & 1.09 \\
\hline 130920 & Hay Springs, NE & 42.684 & 102.689 & 495 & 15.91 & 0.21 \\
\hline 130960 & Gordon, NE & 42.805 & 102.203 & 465 & 15.11 & -0.17 \\
\hline 131010 & Cottonwood Lake, NE & 42.914 & 101.674 & 470 & 15.84 & 1.35 \\
\hline 131020 & Winner, SD & 43.377 & 99.859 & 600 & 16.65 & 2.81 \\
\hline 131130 & O’Neill, NE & 42.458 & 98.647 & 614 & 15.11 & 1.87 \\
\hline 131140 & Grand Island, NE & 40.925 & 98.342 & 666 & 16.32 & 3.50 \\
\hline 131350 & Paxton, NE & 41.124 & 101.356 & 471 & 17.09 & 1.94 \\
\hline 131470 & McCook, NE & 40.202 & 100.625 & 545 & 18.09 & 2.93 \\
\hline 131930 & Lamar, CO & 38.087 & 102.620 & 399 & 20.20 & 2.86 \\
\hline 132090 & Albuquerque, NM & 35.084 & 106.651 & 219 & 21.86 & 5.93 \\
\hline 132180 & Garden City, KS & 37.972 & 100.872 & 485 & 20.25 & 4.10 \\
\hline 132220 & Atwood, KS & 39.807 & 101.042 & 568 & 18.15 & 1.89 \\
\hline 132350 & Grand Junction, CO & 39.064 & 108.550 & 222 & 18.71 & 3.76 \\
\hline 132410 & Grand Junction, CO & 39.064 & 108.550 & 222 & 18.71 & 3.76 \\
\hline 132480 & Twin Falls, ID & 42.563 & 114.460 & 343 & 16.64 & 2.30 \\
\hline 132500 & Letha, ID & 43.894 & 116.647 & 296 & 17.82 & 3.36 \\
\hline 132510 & Alkali Lake, OR & 42.977 & 120.027 & 211 & 17.04 & -1.27 \\
\hline 132570 & Lakeview, OR & 42.189 & 120.345 & 464 & 14.04 & 0.71 \\
\hline 132630 & Alturas, CA & 41.487 & 120.541 & 314 & 17.28 & -0.76 \\
\hline 132650 & Burns, OR & 43.586 & 119.053 & 277 & 15.44 & -0.33 \\
\hline 12320 & Fresno, CA & 36.748 & 119.771 & 285 & 24.24 & 10.15 \\
\hline 12560 & Fresno, CA & 36.748 & 119.771 & 285 & 24.24 & 10.15 \\
\hline
\end{tabular}


Table 2. The effect of the location of saltgrass clone origin on the traits that were measured in the study that considered phenotypic variation in saltgrass growth and time of fall dormancy as a function of geographical and climatic factors at the location of clone origin.

\begin{tabular}{lcc}
\hline Trait & F statistic & $P$ value \\
\hline Canopy height & 3.71 & $0.012^{\mathrm{z}}$ \\
Internode length & 6.20 & 0.001 \\
Leaf length & 3.16 & 0.022 \\
Time of leaf & & \\
$\quad$ browning in fall & 2.45 & 0.055 \\
Leaf width & 1.23 & 0.38 \\
\hline
\end{tabular}

${ }^{\mathrm{z}}$ The level of significance was 0.05 . Factors and interactions with $P<0.05$ were considered significant.

An analysis of variance determined a simple location effect that may or may not be associated with environmental (geographical and climatic) factors at the locations of the clone's origin.

Ehleringer, 1994) determined that more water-efficient plants were larger in a well-watered garden treatment when compared with less water-efficient plants. That study also found no significant differences between more and less water-efficient plants in a limited -water treatment.

Time of fall dormancy had a strong positive correlation with longitude $(r=0.65, P<0.0001)$ and a moderate negative correlation with latitude $(r=-0.335$, $P=0.0303)$. Winter minimum temperatures were positively correlated with time of fall dormancy as well $(r=$ $0.7, P<0.0001)$. This indicates that lower temperatures during the winter leads to earlier dormancy in the fall. Longitude of clone origin and minimum winter temperature were also strongly associated $(r=0.59, P<$ $0.0001)$. Time of fall dormancy had negative correlations with spring $(r=$ $-0.55, P=0.0001)$ and summer precipitation $(r=-0.58, P<0.0001)$, but correlations were positive with fall $(r=0.42, P=0.005)$ and winter $(r=$ $0.54, P=0.0002)$ precipitation. Presumably, a high level of precipitation in September and October may increase the length of growing season or alter time of fall dormancy late in the fall, thereby reducing potential cold hardiness. Linden (2002) reported that a longer growing season resulting from high precipitation levels in fall is an important factor that increases apple tree sensitivity to winter injury.

Regression analysis of saltgrass growth indicated that climatic factors contributed to the variability in growth traits much more than geographical factors. Initially, one of the best four-variable regression models included September and October maximum temperatures and June and
August precipitation [growth $=-11.65+(2.66 \times$ September maximum temperature $)-(2.66 \times$ October maximum temperature $)-(0.09 \times$ June mean precipitation $)+(0.09 \times$ August mean precipitation)]. However, the sign of the coefficients varied for each of the precipitation and temperature variables. This suggested that rate of change was important for summer precipitation and fall temperatures. As a result, the two variables (summer drying and fall cooling) were constructed. Of simple regression models, climatic variables such as summer drying and precipitation during the spring and summer months explained a similar amount of variability: $14 \%$ to $20 \%$. Twovariable regression models suggested that most of the variation $(\approx 50 \%)$ in morphological traits was associated with summer drying and fall cooling $\left(R^{2}=0.495\right)$. Because both summer drying and fall cooling were significantly correlated with PC-1, it seems likely that they are important factors associated with variation in saltgrass growth. The regression model described earlier is shown by the map that summarizes variation in saltgrass growth (Fig. 1). Saltgrass showed growth patterns with low values along the coast and in the midwest, with high values in the Rocky Mountains.

Regression analysis of time of fall dormancy indicated that variation in that trait was a function of both geographical and climatic factors. Longitude was the most important geographical factor and explained $42 \%$ of variability. Of climatic factors, winter, as well as January and February minimum temperatures,

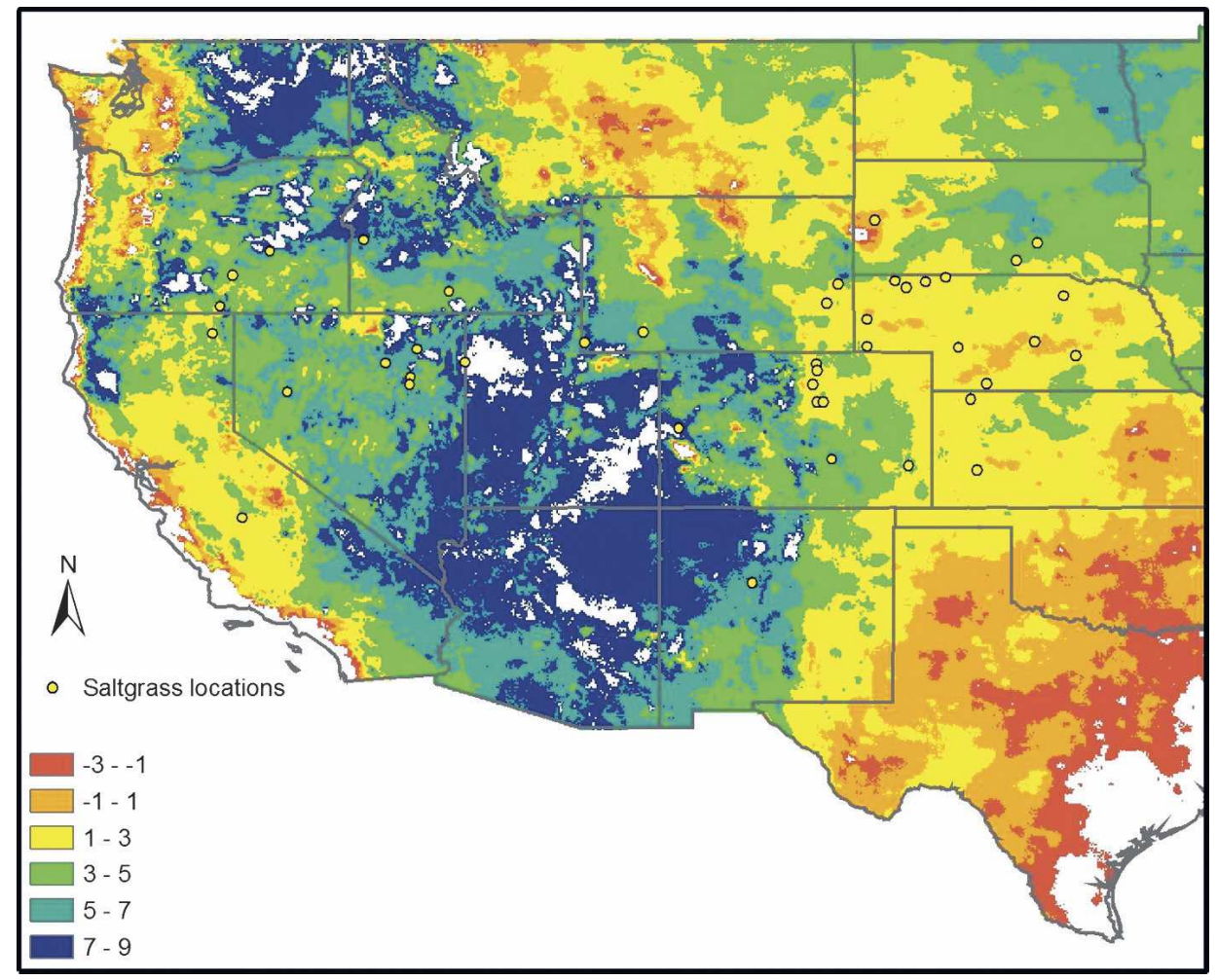

Fig. 1. Geographical variation observed in saltgrass growth. The map presents a multiple regression model in which growth is a function of fall cooling and summer drying [growth $=-11.33+1.80 \times($ September maximum temperature - October maximum temperature) $-0.69 \times$ (June mean precipitation - August mean precipitation)]. Fall cooling presents a difference between maximum temperatures in September and October, and summer drying presents a difference between mean precipitation in June and August. The numbers in the lower left corner present estimated values for saltgrass growth. These values were generated by retrieving the independent variables from the regression equation in the geographical information system data layers. Color groupings are in the units of an SD of the 41 original points of saltgrass clone origin. Each color represents a range of different growth values. 
explained a similar degree of variability in time of leaf browning ( $49 \%$ to $51 \%)$ in simple models. Of the two-variable models, a number of two-variable combinations explained $60 \%$ of the variation. However, based on variability explained in simple regression models, it was concluded that time of leaf browning in fall is strongly related to the winter month minimum temperatures and longitude, but precipitation explained some of the residual variation. The regression model in which time of leaf browning in fall is a function of longitude and February minimum temperature is visually illustrated by the map in Fig. 2. As expected, as source locations move from warmer sites in the West along the coast to cooler sites in the eastern interior of the country, values for time of fall dormancy decrease, and therefore potential cold hardiness increases. This indicates that some clones from western locations may not have sufficient cold tolerance for establishment on eastern sites.

This is the first study that provides information about geographical and climatic factors that contribute to the variation in growth and time of fall dormancy (indicative of cold hardiness) among saltgrass clones. The two variables in this study, growth (PC-1) and time of leaf browning in fall showed different patterns of variation relative to geographical and climatic factors. Although morphological traits showed variation associated with fall cooling and summer drying, variation in time of fall dormancy was strongly associated with longitude and minimum winter temperatures.

Seasonal climatic parameters of summer drying and fall cooling are likely the most important factors for saltgrass growth

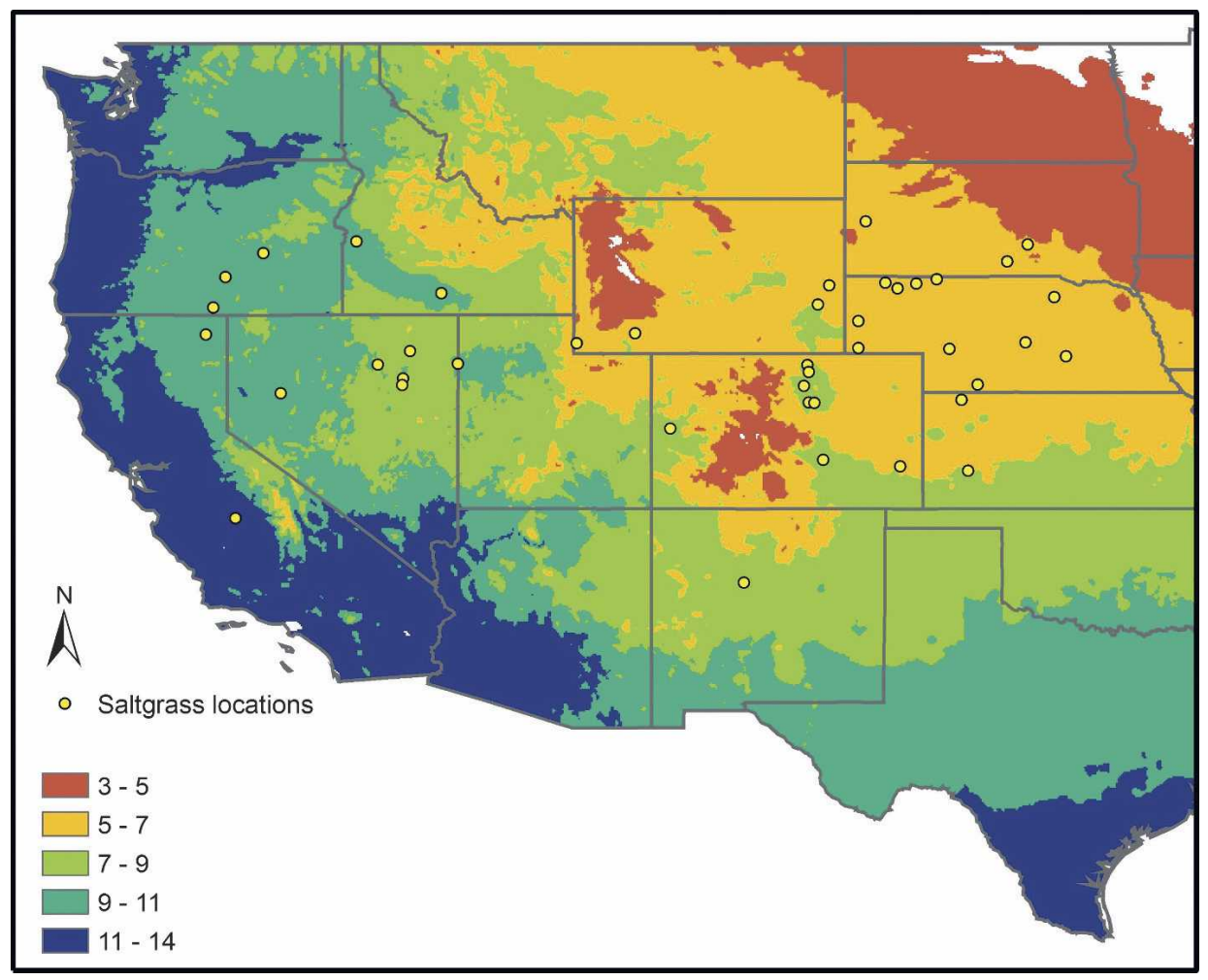

Fig. 2. Geographical variation observed in saltgrass time of fall dormancy. The map presents a multiple regression model in which time of fall dormancy is a function of longitude and February minimum temperature [time of fall dormancy $=-0.527+(0.99 \times$ longitude $)+(0.331 \times$ February minimum temperature $)]$. The numbers in the lower left corner present estimated values for time of saltgrass fall dormancy. These values were generated by retrieving the independent variables from the regression equation in the geographical information system data layers. Color groupings are in the units of an SD of the 41 original points of saltgrass clone origin. Each color represents range of different time of fall dormancy values. adaptation in the central and western United States. Decreased precipitation during the summer has likely resulted in natural selection for decreased growth during summer water deficiency. This was presumably an adaptation to summer drought. On the other hand, decreased temperatures in fall (or fall cooling) seem to have resulted in natural selection for increased growth as soon as conditions for growth become favorable. This is probably because lower temperatures in the fall reduce water requirements. Many perennial grasses in semiarid regions show a very slow growth rate during the summer drought and start growing faster in fall when temperatures and photoperiod decrease (Pugnarie et al., 1996). This type of association between growth variation and climatic factors is also found in studies with several evergreen woody species. Biondi and Fessenden (1999) studied variation in lodgepole pine (Pinus contorta Dougl.) growth characteristics relative to climatic factors in California. They found a high negative correlation between July temperature and growth of lodgepole pine. The increased temperature in July caused greater water stress that in turn resulted in decreased growth. In a similar study with Douglas fir [Pseudotsuga menziesii (Mirbel) Franco] in western Oregon and Washington, St Clair et al. (2005) found that seedling sources with earlier bud burst produced increased growth before water limitation, and generally came from areas with higher summer temperature and lower summer precipitation. Furthermore, some morphological features, like smaller leaves in grasses that reduce transpiration, have a significant role in adaptation to an arid environment (Erickson et al., 2004).

Geographical variation in cold hardiness is generally considered an adaptive response to environmental factors, such as temperature, photoperiod, and moisture (Balduman et al., 1999). Many plant species have shown latitudinal variation in cold hardiness (Finne et al., 2000; Hannerz and Westin, 2000; Hurme et al., 1997; Yao and Tigerstedt, 1995) or in phenological traits related to cold hardiness, such as growth cessation and dormancy (Ingvarsson et al., 2005). In our study, the north-south interval of tested clones might not be broad enough to show strong latitudinal variation in time of leaf browning in fall. Time of fall dormancy showed east-west variation, which was associated with minimum temperatures during the winter months and rainfall pattern, which were highly correlated with longitude. Cold hardiness was greater in clones from eastern locations, which is likely the result of the differences in winter temperatures and rainfall patterns between eastern and western sites. The climate on western sites is milder than that on eastern sites, and more of the rainfall happens during the winter months. Our results indicate that lower temperatures, particularly temperatures during the winter months, have 
resulted in selection of greater cold hardiness (earlier fall dormancy) in saltgrass clones from eastern sites. Greater potential cold hardiness, associated with greater spring and summer precipitation, occurs in clones from eastern locations. Johnson et al. (2001) reported a relationship between buffalograss (Buchloe dactyloides Nutt.) cold hardiness and longitude. In that study, hexaploid clones with greater cold hardiness were more common in the eastern areas. On the other hand, tetraploid clones that are less cold hardy were only found in the western parts of the collection area. Our results also correspond to a similar study with scots pine (Pinus sylvestris L.) cold hardiness (Anderson and Fedorkov, 2004). They found a strong association between scots pine cold hardiness and longitude, and interpreted longitudinal effects as the result of differences in temperatures between East and West. Cooler temperatures on eastern sites, especially in October (which is the most important for gaining winter hardiness) enabled faster cold acclimation and greater cold hardiness. In a study with Douglas fir, Balduman et al. (1999) found greater east-west variation in cold hardiness compared with north-south variation. In that study, cold hardiness increased with lower winter temperatures.

In summary, seasonal climatic variables were better than geographical variables in explaining variation in growth of saltgrass ecotypes. Decreased growth may be an adaptation to drought during the summer months in the central and western United States. In the case of decreased growth, it seems likely that natural selection has resulted in morphological traits that relate to drought avoidance. On the other hand, selection for increased growth during fall cooling, and therefore a period of lower drought, have also resulted in variation among saltgrass clones. Time of fall dormancy had a discernible pattern on the landscape. Longitude of clone origin is likely associated with different temperature regimes during the winter, which have resulted in natural selection for cold hardiness in saltgrass clones. Overall, our results indicate variation in saltgrass growth (morphology) and time of fall dormancy are related to the environmental factors of source location. A saltgrass breeding program should therefore maintain geographical structure with regard to those traits analyzed in this study. Traits of saltgrass growth and time of leaf browning in fall (cold hardiness) showed a relationship with environmental factors at the source location, indicating that these traits may be of adaptive importance.

This study has not determined genetic variation in measured traits. Relations between molecular markers and traits examined in this study should provide a first step in finding specific genes responsible for phenotypic variation in saltgrass.

\section{Literature Cited}

Anderson, B. and A. Fedorkov. 2004. Longitudinal differences in scots pine frost hardiness. Silvae Genet. 53:76-79.

Balduman, L.M., S.N. Aitken, M. Harmon, and W.T. Adams. 1999. Genetic variation in cold hardiness of Douglas fir in relation to parent tree environment. Can. J. For. Res. 29:62-72.

Biondi, F. and J.E. Fessenden. 1999. Response of lodgepole pine growth to $\mathrm{CO}_{2}$, degassing at Mammoth Mountain, California. Ecology 80:2420-2426.

Casler, M.D. and R.R. Duncan. 2003. Origin of the turfgrasses, p. 523. In: M.D. Cusler and R.R. Duncan (eds.). Turfgrass biology, genetics and breeding. Wiley, Hoboken, NJ.

Ceccarelli, S., E. Falistocco, and P.G. Cionini. 1992. Variation of genome size and organization within hexaploid Festuca arundinacea. Theor. Appl. Genet. 83:273-278.
Daly, C., R.P. Neilson, and D.L. Phillips. 1994. A statisticaltopographic model for mapping climatological precipitation over mountainous terrain. J. Appl. Meteorol. 33:140-158.

Donovan, L.A. and J.R. Ehleringer. 1994. Potential for selection on plants for water-use efficiency as estimated by carbon isotope discrimination. Amer. J. Bot. 81:927-935.

Eppley, S.M., M.L. Stanton, and R.C. Grosberg. 1998. Intrapopulation sex ratio variation in the salt grass Distichlis spicata. Amer. Naturalist 152:659-670.

Erickson, V.J., N.L. Mandel, and F.C. Sorensen. 2004. Landscape patterns of phenotypic variation and population structuring in a selfing grass, Elymus glaucus (blue wildrye). Can. J. Bot. 82:17761789.

Finne, M.A., O.A. Rognli, and I. Schjelderup. 2000. Genetic variation in a Norwegian germplasm collection of white clover (Trifolium repens L.)-1. Population differences in agronomic characteristics. Euphytica 112:33-44.

Hannerz, M. and J. Westin. 2000. Growth cessation and autumn-frost hardiness in one-year-old Picea abies progenies from seed orchards and natural stands. Scand. J. For. Res. 15:309-317.

Hauser, A.S. 2006. Species: Distichlis spicata. 28 Aug. 2007 $<$ http://www.fs.fed.us/database/feis/plants/graminoid/disspi/ introductory.html $>$.

Hughes, H.G., D.K. Christensen, A.J. Koski, and S.D. Reid. 2002. Desert saltgrass: A potential new turfgrass. 6 Sept. 2007. <http:// turf.lib.msu.edu/tero/v01/n12.pdf>.

Humphreys, M.O. and C.F. Eagles. 1988. Assessment of perennial ryegrass (Lolium perenne L.) for breeding. I. Freezing tolerance. Euphytica 38:75-84.

Hurme, P., T. Repo, O. Savolainene, and T. Paakkonen. 1997. Climatic adaptation of budset and frost hardiness in scots pine (Pinus silvestris). Can. J. For. Res. 27:716-723.

Ingvarsson, P.K., M.V. Garcia, D. Hall, V. Laquez, and S. Jansson. 2005. Clinal variation in $p h y B 2$, a candidate gene for day-lengthinduced growth cessation and bud set, across a latitudinal gradient in European aspen (Populus tremula). Genetics 172:1845-1853.

Johnson, P.G., K.E. Kenworthy, D.L. Auld, and T.P. Piordan. 2001. Distribution of buffalograss polyploidy variation in the southern Great Plains. Crop Sci. 41:909-913.

Kopec, D.M. and K.B. Marcum. 2001. Desert saltgrass: A potential new turfgrass species. U.S. Golf Assn. Green Section Record 39: 6-8.

Linden, L. 2002. Measuring cold hardiness in woody plants. University of Helsinki, Finland. PhD diss.

Maps a la carte, Inc. 1999. Browse topographic maps and aerial photographs by place name, topo map name, or county name. 27 Aug. 2007. <http://www.topozone.com/viewmaps.asp>.

Pugnarie, F.I., P. Haase, L.D. Incoll, and S.C. Clark. 1996. Response of the tussock grass (Stipa tenacissima) to watering in a semi-arid environment. Funct. Ecol. 10:265-274.

Ram, A., M. Zaccai, D. Pasternak, and A. Bustan. 2004. Analysis of phenotypic and genetic polymorphism among accessions of saltgrass (Distichlis spicata). Genet. Resource Crop Evol. 51:687-699.

Rukavina, H. 2006. Phenotypic variability, cold hardiness and flowering induction of saltgrass [Distichlis spicata (L.) Greene] clones. Colorado State University, Fort Collins, CO. PhD diss.

Rukavina, H., H.G. Hughes, and Y.L. Qian. 2007. Freezing tolerance of 27 saltgrass ecotypes from three cold hardiness zones. HortScience 42:157-160.

St Clair, J.B., N.L. Mandel, and K.W. Vance-Borland. 2005. Genecology of Douglas fir in western Oregon and Washington. Ann. Bot. (Lond.) 96:1199-1214.

Sugiyama, S. 2003. Geographical distribution and phenotypic differentiation in populations of Dactylis glomerata L. in Japan. Plant Ecol. 169:295-305.

Yao, Y.M. and P.M.A. Tigerstedt. 1995. Geographical variation of growth rhythm, height, and hardiness and their relations in Hippophae rhamnoides. J. Amer. Soc. Hort. Sci. 120:691-698. 